Luneva, I. (2020). Creating a museum space for the preservation of contemporary art of fashion on the example of Italy. 21st century: history and modernity of art. Collection of Scientific Articles. European Scientific eJournal, 4 (4), 64-76. Hlučín-Bobrovníky: “Anisiia Tomanek” OSVČ.

Аунева, И. (2020). СозАание музейного пространства Аля сохранения современного искусства моды на примере Италии. 21st century: history and modernity of art. Collection of Scientific Articles. European Scientific e-Journal, 4 (4), 64-76. Hlučín-Bobrovníky: “Anisiia Tomanek” OSVČ.

DOI: $10.47451 / \operatorname{art} 2020-11-002$

EOI: $10.11244 / \operatorname{art} 2020-11-002$

The paper is published in Crossref, Internet Archive, Google Scholar, Academic Resource Index ResearchBib, JGate, ISI, CiteFactor, ICI, eLibrary databases.

Irina Luneva

PhD student, Art Historian, Researcher in the field of fashion

The direction of Museum Curation

Museology and Protection of Cultural and Natural Heritage

St Petersburg State University

St Petersburg, Russia.

E-mail: adominka.ira@yandex.ru

\title{
Creating a museum space for the preservation of contemporary art of fashion on the example of Italy
}

\section{Abstract:}

This article is dedicated to fashionable exhibitions and museum-type corporate art institutions, which are one of the characteristic features of the museum system and one of the most successful development strategies. These can be items of decorative and applied art that reject the usual commercial space and want to occupy a place not just in a museum, but definitely exhibit next to artworks. To understand this problem and the stages of the process of establishing and developing a fashion museum, you need to analyze the experience of the world's leading museums located in the main fashion centres. The purpose of the study was to analyze the status of the Italian Fashion Institute as one of the world's largest fashion centres. The author concludes that every year there is an increasing interest in studying the history of costume, and there are prerequisites for creating exhibitions and museums dedicated not only to the history of costume but also to modern fashion in general. The example of Italy's experience, which many people associate with one of the world's fashion centres, was considered in order to reflect on modern exhibition activities.

\section{Keywords:}

fashion museum, contemporary Italian fashion, museology, costume, foreign experience, modern art, fashion archives, cultural heritage, ICOM.

\section{Ирина Аунёва}

магистрант, историк искусств, исследователь в области моды направление «Музейное кураторство» Санкт-Петербургский государственный университет 
Санкт-Петербург, Россия

E-mail: adominka.ira@yandex.ru

\title{
Создание музейного пространства Аця сохранения современного искусства моды на примере Италии
}

\begin{abstract}
Аннотачия:
Статья посвящена выставкам моды и корпоративным художественным институтам музейного типа, которые явАяются одной из характерных особенностей музейной системы и одной из наиболее успешных стратегий развития. Это могут быть предметы декоративноприкцадного искусства, которые отвергают обычное коммерческое пространство и хотят занять место не просто в музее, но обязательно выставцяться рядом с произведениями искусства. Чтобы понять Аанную проблему и этапы процесса создания и развития музея моды, необходимо проанализировать опыт ведущих мировых музеев, расположенных в основных центрах моды. Целью исследования был анализ статуса Итальянского института моды как одного из крупнейших мировых центров моды. Автор приходит к выводу, что с каждым годом растёт интерес к изучению истории костюма, и есть предпосылки Аля созАания выставок и музеев, посвященных не только истории костюма, но и современной моде в целом. Пример опыта Италии, который у многих ассоциируется с одним из мировых центров моды, был рассмотрен Аля того, чтобы отразить современную выставочную Аеятельность.
\end{abstract}

Ключевые слова:

музей моды, современная итальянская мода, музееведение, костюм, зарубежный опыт, современное искусство, архивы моды, культурное наследие, ICОМ.

\section{Introduction}

Modern Russian fashion, from the point of view of museum expositions, is an understudied phenomenon. There is a lack of sources of literature on contemporary Russian fashion. There are quite a few publications devoted to current fashion and costume, but the history of fashion in Russia is practically not disclosed at the Institute of Museology, so it is not broadcast through fashion museums. Using the example of St Petersburg, we can see that fashion museums have a clear focus on the exposition of costumes and everyday objects from the 18th to 19th centuries, for example, the Museum of Costume, the St Petersburg Museum of Theatre and Music, and the Museum of Russian Drama. Russian central museum and exhibition centre, the Museum of Fashion, is no exception, as it regularly displays costumes from the 19th and first half of the 20th centuries, as well as fashion shows.

To understand this problem and the stages of the process of establishing and developing a fashion museum, it is necessary to analyze the experience of the world's 
leading museums located in the main fashion centres. The largest collection in Russia today is in the State Hermitage Museum Restoration, the Old Village Curatorial Centre. Now the Hermitage has started to buy or accept works by contemporary designers in order to preserve this period for future generations. Fashionable exhibitions or the establishment of museum-type corporate art spaces, which are one of the characteristic features of the museum system and one of the most successful development strategies to date. These may be decorative-applied art items that reject the usual commercial space and want to occupy a place not just in a museum, but definitely exhibit next to artworks. And there is no unambiguous answer to who wants it more: the art director of the brand, the museum itself, the artist or the viewer. It is necessary to study this phenomenon as long as it is lively and relevant, which can serve as a material for fashion historians in the future.

Literature on this topic is divided into two sections. The first section includes journalistic scientific articles in electronic resources on the theory of fashion and collecting, which address various issues in contemporary fashion.

Russian fashion designer and designer Natalia Aleksandrovna Valevskaya in her article entitled "A suit as a collection item" No 27. She analyzes by examples from the Russian history of collecting a suit and individual items of the turn of 19th and 20th centuries. The author concludes from the examples that there has been no interest in the history of the Russian costume for a long time, but the prerequisites for the creation of a museum of costume in the country as such have not appeared. In Natalia Aleksandrovna Valevskaya's second article "Justification of the need to create the first museum of fashion and costume in Russia" No 5. She considers the question of creation of the first fashion museum in Russia on the examples of modern Russian exhibitions connected with costume and compares them with foreign experience of leading fashion museums of the USA, Europe and Asia (Valevskaya, 2012).

In his scientific article "Fashion and Art: Interaction in the Context of Representations" No. 1, O.N. Lagoda writes about the attitude of various specialists in the fashion industry to whether fashion can be considered an art. She talks about how fashion and contemporary art interact in the process of creating designer things, using examples of fashion designers, and focuses on modern science and interaction, the symbiosis between fashion and art. The researcher reveals the distinctive features of these phenomena and the close relationship between them. By analyzing, fashion shows and exhibitions in museums, we can trace how the author compares two different formats of contemporary art representations with signs of post-modern 
culture. As a result, she claims that fashion and art are two phenomena that are in complex symbiotic relations and feed each other (Lagoda, 2014).

The largest theoretician and collector in the field of costume is Alexander Vasiliev. He focuses on the need for active research into Russian fashion in general and the modern art process in this field.

The second section includes materials on the Fashion Museum. This is video content from the Empathy Manuchi and Levovich Culture Headquarters channels on the YouTube portal. These are two current projects that use the format of a live dialogue with interesting creative people, in which the modern art of fashion has a prominent place.

In the course of the survey, the main parameters of the survey were formed and clarified.

The object of research was the contemporary art of fashion. The subject of the study was the Italian Fashion Institute as one of the world's largest fashion centres.

The purpose of the study was to analyze the status of the Italian Fashion Institute as one of the world's largest fashion centres.

On the basis of the purpose, the study carried out the following tasks:

- form a theoretical basis for the research;

- $\quad$ highlight the main areas of activity of the largest fashion museum centres;

- analyse the status of the Fashion Institute in Italy;

- identify the main problems in creating a single regional fashion museum as part of a fashion institute.

\section{Theoretical basis for research}

In Yevgeny Arturovich Abrose's monograph Psychology of Fashion, he writes about approaches that exist in different fields of science, from psychology to cultural anthropology, in the study of the fashion phenomenon. He considers ways of developing fashion psychology, which are in the latest achievements and in the main directions related to the study of personality and communication processes. This study predicts the social and psychological aspects of fashion functioning in modern society. For students, postgraduates, teachers specializing in psychology, culturology, sociology, art criticism and other humanities, and for anyone interested in fashion psychology (Abrose, 2016).

In an article of the team of scientists E.F. Abroze, A.G. Buychik and S.V. Lebedev "Psychological culturology as a new science" it makes a proposal to separate the fashion into a separate culturology direction "Fashionology" as a "section of 
psychological culturology, which studies the impact of culture, tangible and intangible cultural heritage, on the fashion industry and the psychological development of different social groups, and vice versa, the impact of individual representatives of different social groups on the psychological development of society through the transformation of tangible and intangible cultural heritage in the field of culture" (Abroze et al., 2016).

In Anastasiy Zhilyayeva's article "Features of modern fashion" № 21, she focuses on the development of this phenomenon as a socio-cultural one, viewing fashion as a trend consisting of different styles and images, which promotes personal self-expression. The author of this work notes that modern fashion is an indicator of the development of society (Zhilyaeva, 2020).

L.A. Klimova and V.Y. Makovetskaya in their article "Costume as an Object of Museum and Exhibition Space" No. 19 consider the museum as a technology and organization of exhibition activities to show the costume as an exhibit. The examples of various exhibitions show how new technologies are being introduced in the practice of museum exhibitions: from the classic presentation of clothing on dummies to a virtual 3D technology presentation (Klimova \& Makovetskaya, 2015).

In the article "The Principle of Interpretation as an Artistic Method in the Creativity of St Petersburg Designers" No. 1 Andrey Alexandrovich Korovko considers the contemporary art of fashion from the perspective of the method of interpretation of contemporary practices. The author focuses on the cyclical nature of contemporary art of fashion and pays attention to artistic methods using the example of Petersburg fashion designers, which are related to the principles of interpretation - borrowing, citation, stylization - and also considers collaborations of St Petersburg brands with graphic artists, which determines the originality of the work of St Petersburg fashion designers in addressing the artistic and cultural heritage (Korovko, 2019).

In the article of Igor Nikolaevich Tyurin and Varvara Getmantseva "New Approaches in Modern Strategy for the Development of the Fashion Industry" No. 22 , they consider new approaches to designing fashion collections about the changes that have taken place in modern fashion in recent years. The authors highlight the main methods used in the creative approach of the design process and changes in aesthetic norms in the design of a suit, and also analyze the use of symbolic signs in the design of modern clothing models (Tyurin \& Getmantseva, 2018).

Louise Wallenberg, a professor at Stockholm University's Department of Fashion Media Studies, writes in his article "Art, life, and the fashion museum: for a more solidarian exhibition practice" No 17 that fashion connects life and art. The 
author notes that the museum is a particularly important space, which consists of an exhibition of decorative and applied art objects and has a link between aesthetic and secular, between art and life. She notes that more and more must be dedicated to fashion, not only as a cultural, social and, last but not least, economic phenomenon. The author looks at the museum from the point of view of demonstrating and discussing the close connection between fashion and real life and the features that make it possible. Louise Wallenberg argues that the museum's curatorial practice should lessen its efforts to offer its visitors impressive exhibitions of designer fashion and instead focus on the urgent search for and need to reform the fashion industry, where textile and clothing workers can truly lead safe and dignified lives (Wallenberg, 2020).

In the article "Perceptions of an Electronic Dress as Fashion, Art, and Costume", Ph. D. Virginia Rolling, associate professor at Georgia Southern University, and Ph. D. Karla P. Teel, associate professor of consumer science and design at the Auburn University of Wrangler, look at the kind of electronic dress from the exhibition point of view as a museum object of art. The authors use a qualitative approach based on the theory that they interviewed 44,000 members of the Millennium generation during various views of the dress. Based on the survey results, they have developed a basis for defining clothing as fashion, art or costume. This survey is useful for various areas such as fashion marketing and design, performing arts and art museums (Rolling \& Teel, 2020).

Thus, taking into account all the peculiarities, every year there is an increasing interest in studying the history of the costume in Russia. There are prerequisites for the creation of exhibitions and museums dedicated not only to the history of the costume, but also to modern fashion in general. During the Soviet period, the main goal in creating clothes was to make them comfortable and comfortable, and no one even thought about forming a sense of style among citizens during the Soviet era. But over the past 30 years, everything has gradually started to change: fashion designers are turning from artisans into artists, there is a need to talk about fashion as an art, fashion and costume are beginning to be studied as a phenomenon, and costume and fashion are becoming relevant to exhibition practices as well, thanks to the visualization of culture in the 21 st century. To understand modern exhibition activities, it is necessary to analyze domestic and foreign experience using the example of the main leading museums in the field of costume history.

\section{Updating the relationship between fashion and museum concepts}


Fashion is a phenomenon that conditions and influences the lives of each of us, getting more and more space in the mass media and social networks. Fashion is often regarded as a kind of industry, which is one of the directions, i.e., it is considered from the economic point of view. Fashion deserves to be shown and exhibited in a museum. It can be considered the cultural heritage of its nation. It symbolizes a kind of cultural capital. Fashion expresses the historical and social aspects of a nation's life in general. Fashion is always the child of a nation of its time. It represents both economic and cultural aspects. It is the conquest and achievements that the country has at all levels.

We can talk about it as a platform for observation with regard to different sides of reality. In order to speak closer to the point. That is, how fashion and museum can influence each other and how they can be connected. We need to talk about what a museum is and what fashion is. And what we mean by that at the moment.

A museum as a concept is now very often considered to be something that is covered with dust or broken moths. The concept of a museum is still very important. Above all, a museum allows people to explore different collections of art of all kinds, because it is a certain institution that, by definition, preserves national heritage and which, after all, is used by citizens of a country or other country.

ICOM is the International Council of Museums. It has developed a definition of a museum that, with its princes, satisfies this concept on an international level. They now have a 2007 definition that their organization has adopted, believing that a museum is such a permanent, often non-profit institution, open to the public and necessarily engaged in the exploration of the material or non-material assets of the human being and the environment around it. It collects evidence, conserves it, passes it on to new generations and presents objects and objects both to meet the personal spiritual needs of the individual and for education. In 2014, the Ministry of Culture of the Russian Federation also approved the concept of cultural achievements, which is still being implemented today. However, the actualization of this concept is changing rapidly and is no longer fully satisfying society as it no longer sufficiently reflects what a modern museum is becoming.

ICOM thus got everyone thinking and invited its members to submit their own proposals in order to add the characteristics needed to define today's museum. Above all, it is accessibility for people to go there with pleasure. It is also necessary for a museum to actively preserve the achievements of a particular state or its subject. Social responsibility is also particularly important when developing museum concepts. 
On the basis of numerous suggestions from ICOM member countries, additions have been developed.

What is a museum? Museums are democratizing, inclusive and polyphonic spaces for critical dialogue about the pasts and the futures. Acknowledging and addressing the conflicts and challenges of the present, they hold artefacts and specimens in trust for society, safeguard diverse memories for future generations and guarantee equal rights and equal access to heritage for all people. Museums are not for profit. They are participatory and transparent, and work in active partnership with and for diverse communities to collect, preserve, research, internet exhibit and enhance understandings of the world, aiming to contribute to human dignity and social justice, global equality and planetary wellbeing (Executive Board of ICOM).

The museum retains those moments that have been highlighted as important, i.e., the museum is an institution that does not exist for profit, but is a kind of bridge between the past and the future, emphasizing the role of the younger generation in development. As for the purpose of museums, they should remain involved in the preservation and protection of cultural and natural heritage.

Thus, a new essence of the museum was defined as a social and cultural institution of each state individually and the world community as a whole. After we have analyzed the main points that characterize a museum today, we need to emphasize the concept of fashion, as there is a very close link between fashion and museum.

\section{International experience of world fashion museums}

Of the most famous fashion museums, we should first highlight The Museum at the Fashion Institute of Technology in New York and The Victoria and Albert Textiles and Fashion Collection in London, which has a section on fashion history.

The Costume Institute at the Metropolitan Museum of Art - MET in New York is considered to be the third largest fashion museum, where fashion technologies are actively developed and, accordingly, the largest curators of the international fashion market work. In September 2019, representatives from this organization came to Rome for the Fashion Colloquium to discuss on the topic of "The Evolution of Fashion and its Relationship to Museums".

The MET Museum consists of thirty-three thousand items and exhibits that are related to fashion. This collection includes not only clothes, but also accessories for women, men and children from the 15th century to the present day. MET owns an excellent laboratory, which employs various researchers and specialists who will help direct or come to study what they have accumulated or get advice, etc. 
Clothing and accessories that need special historical and cultural protection are collected there: impressive fabrics, embroidery, furs that are the hardest to keep. After a closing period for the restoration, which lasted only two years in 2014, MET and its fashion section were reopened. The work of the laboratory itself must be emphasized in particular. Despite the fact that there are institutions that already demonstrate the need for a link between fashion and museums.

However, some art historians believe that such an easy and transient phenomenon as fashion is worthy to be found in solid museums. This was, of course, a controversial thing, because fashion is the part of art that has an industrial element in it. On the one hand, this element is inextricably linked to various technological and production processes, particularly the history of textiles. On the other hand, fashion, as well as design, is in the practical part of the cultural industry.

The museum houses many of the exhibits from fashion exhibitions that have been held in various places over the past 20 years. It should be noted that, on the one hand, these were very interesting exhibitions, which had a reaction to the visitor. On the other hand, there were elements of contradiction, because criticisms were often directed at curators of fashion exhibitions who sought to emphasize the economic aspect related to fashion and the income they received, i.e., it was important for them to note how much any fashion element is a symbol of the country. Very often exhibition curators were accused of not always being sensitive to the historical point of view.

Since 1997 alone, 25 fashion shows have been held in The Museum at FIT. Some of the exhibits have gone down in history, but still remain in the memory of those who are actually interested in fashion on purpose. It is important to note that in recent years the intensity of fashion exhibitions has attracted the attention of a global audience.

One of the important aspects of holding and organizing fashion exhibitions is how fashion is constantly evolving and changing. Fast Fashion is also one of the most important phenomena. This phenomenon is mainly related to brands that are rapidly developing collections of famous high fashion designers in Paris or Milan. These brands are beginning to quickly produce extremely similar style products with those models that have been previously shown. Very many of these brands manage to change their collections 4 times a year, not 1-2 times, but sometimes even every week. Any one of us can change our wardrobe very quickly with some new and much more acceptable things. This shows that we are democratizing and globalizing in fashion. 
Thus, some art historians believe that fashion is a phenomenon worthy of being in museums. Using the example of three of the world's leading museums associated with the history of costume. They analyzed one aspect of holding and organizing fashion exhibitions. Among the most famous museums, we should consider the Italian fashion museum issue as an example.

\section{Problems of fashion museumization in Italy}

When it comes to the leading fashion countries, it is necessary to consider the example of Italy as one of the world's fashion centres. Italy does not have a national fashion museum, despite the fact that Italian fashion stands alongside French fashion and is one of the most important in the world. In this respect, the Made in Italy brand is a kind of national business card of the country.

Italian fashion shows how modern this element is, multifaceted, lively, dynamic and certainly a cultural phenomenon in all its manifestations, and in this sense, Italy needs an institution like a fashion museum at the national level. There are some local things that are important that are related to the fashion field. We are talking not only about fashion, but also those laboratories where artisans, archives, and others work.

In 2018, the Ministry of Culture held an event related to fashion studies. A commission was organized to decide what public policy could be to preserve and use Italian fashion as part of the national cultural heritage, and various attempts were made to study the phenomenon. However, this has not been successful.

Thus, the result in itself is still missing, even though some work has been done by the commission. The commission consisted of experts from various fields: fashion journalists, art historians, various professors from fashion and costume academies, leading museum workers. The commission immediately decided to work in such a way as to capture all the fashion elements that already exist in Italy, and at the same time they decided whether it was necessary to create such a museum. However, the priority question was what had been done and what things still need to be done in order for the museum to begin to exist.

On this basis, it became clear that there are approximately 600 different organizations in Italy. These are small and large museums that preserve collections of costume history. For example, the Palazzo Pitti Fashion and Costume Museum in Florence. This museum has exhibitions dedicated to men's fashion in honour of the 30th anniversary of Pitti's international demonstrations. This famous art collection is a permanent exhibit. In any case, it is only a partial representation of the fashion phenomenon in Italy. 
In addition to various public institutions like Palazzo Pitti, there are around 600 organizations, some of which are private museums, such as the Gucci Garden Museum in Florence. This museum has a collection of icons of the style of this fashion house, where you can buy some items that are specially designed for this museum in Florence.

Another famous museum, Ferragamo, is named after an Italian family that deals with the most fashionable shoes in Italy. This is a very interesting museum, which shows the visitor how important the element of craftsmanship and quality of footwear processing is. How shoes were created, how models were built, why they are like now and depending on the historical period, for example, there are periods from which there are no materials at present.

Milan hosts the Palazzo Morando Museum, which is a private large collection of costumes. It is a large city museum, but is partly a fashion museum. At the Italian level, Milan and Florence are two cities where fashion is more common.

The Ministry's commission in Italy has concluded that a large national fashion museum is needed, but it may not exist in the same city. It is precisely because there are different cents, which have different specifics, where they find their own style. It may be a single institution, but it will have branches in different parts of the city.

As for modern fashion in the history of fashion and costume, there are two other important cities besides Milan and Florence: Rome and Naples. In Rome, the emphasis is particularly on theatrical costume, and Naples is more of a man's suit. The whole of Italy has extremely interesting handicraft laboratories in various parts of the city.

In addition, there are archives, which are often held by individuals and which can be taken into account for the creation of a public museum. And this is another important topic that has been emphasized. Archiving fashion is a special area that the Ministry of Culture in Italy, which deals with archives, follows. It has studied, collected and taken inventory of all the data relating to fashion. Based on this, a portal called 20th Century Archive was created. This archive is constantly working to collect everything that was in the 20th century in Italy. This was an important work that was introduced by this commission. It lasted many years and made it possible to collect a huge amount of data, which is a very important document. This is the bridge between «Past and Future», a document that must be obligatory and passed on to the future generation.

Thus, at present Italian fashion is associated with Milan. This commission, which considered it important to focus on the origin of Italian fashion. In order to talk about no one, it is necessary to understand that a museum is not a box with 
beautiful dresses, but a place where you can engage in scientific detail, organize conferences and seminars that will be interesting not only for young people but also for novice designers.

\section{Conclusion}

Thus, every year there is an increasing interest in studying the history of costume, and there are prerequisites for creating exhibitions and museums dedicated not only to the history of costume but also to modern fashion in general. The example of Italy's experience, which many people associate with one of the world's fashion centres, was considered in order to reflect on modern exhibition activities. Fashion is not just an opportunity to somehow protect oneself from the phenomena of nature. It is also an expression, a character and a historical, social moment in which we are today. In Italy, there are economic areas that are currently actively exploring the specifics of local fashion traditions. It is important to emphasize that the birth of high Italian fashion is inseparably linked to the economic boom of the 1950s. Gradually, the phenomenon of Fast Fashion emerged, which is still relevant in Italy today. In terms of museum activities, fashion is generally perceived not only as an industry, but also as an economic component. Very often this criticism is based on the fact that any fashion exhibition is, in a way, an advertisement for a particular brand.

As for the Museum of Italian Fashion, it should be noted that it is increasingly important to synthesize the idea of museification of fashion items from numerous local centres for the preservation of tangible cultural heritage, and the very organization of a single museum of Italian fashion, which should not only preserve but also promote the basic values of the philosophy of Italian fashion.

At the same time, it is important to note the complexity of creating such an integrated fashion institute within one country. In addition, today the Italian social elite understands fashion not as a historically established civilization brand, but only as a social phenomenon constantly transforming over time. This perception is changing, but not enough. The increasing number of fashion exhibitions within museums can be seen as a positive moment, in particular in order to bring the fashion phenomenon closer to high art.

The Italian experience of perception of fashion as a social institution can be useful for analyzing the place of Russian fashion in the development of society and actualizing the need to create a single fashion museum, which will include not only the achievements of the national industry, but also present a real diversity of regional styles, preserving their images and concepts for future generations. 


\section{References:}

Abrose, E.A. (2016). Psychology of fashion: cultural studies review. St Petersburg: Kultinformpress Publishing House. (in Russian)

Abroze, E.A., Buychik, A.G., Lebedev, S.V. (2016). Psychological culturology as a new science. Questions of Modern Science: collection of scientific monographs, 11, 22-40. Moscow: Internauka Publishing House. (in Russian)

Executive Board of ICOM. Retrieved July 15, 2020 from https://icom.museum/en/about-us/executive-board/

Klimova, L.A., Makovetskaya, V.Y. (2015). Costume as an object of museum and exhibition space. Proceedings of the Rostov State University of Civil Engineering, 19 (19), 1, 133-143. (in Russian)

Korovko, A.A. (2019). The principle of interpretation as an artistic method in the work of St Petersburg designers. Costumology, 1, 4, 8. (in Russian)

Lagoda, O.N. (2014). Fashion and art: interaction in the context of representations. Bulletin of the Kharkiv State Academy of Design and Arts, 1, 20-26. (in Russian)

Rolling, V., Teel, K.P. (2020). Perceptions of an electronic dress as fashion, art, and costume, dress.

Tyurin, I.N., Getmantseva, V.V. (2018). New approaches in the modern strategy of fashion Industry Development. Synergy of Sciences, 22, 739-749. (in Russian)

Valevskaya, N.A. (2012). Justification of the need to create the first museum of fashion and costume in Russia. Bulletin of the Chelyabinsk State Pedagogical University, 5, 229-235. (in Russian)

Valevskaya, N.A. (2012). Costume as a collection item. Proceedings of the V.G. Belinsky Penza State Pedagogical University, 27, 1-3. (in Russian)

Wallenberg, L. (2020). Art, life, and the fashion museum: for a more solidarian exhibition practice. Fash Text, 7, 17.

Zhilyaeva, A.A. (2020, March 15). Features of modern fashion. Young Scientist. Retrieved November 6, 2020 from https://moluch.ru/archive/311/70303/ (in Russian)

9th session in Paris on 21-22 July 2019. Extraordinary General Assembly, on 7 September 2019 in Kyoto. Retrieved January 19, 2020 from https://icom.museum/en/news/icom-announces-the-alternative-museumdefinition-that-will-be-subject-to-a-vote/ (in Russian) 